\title{
How does glucose regulate the human pancreatic A cell in vivo?
}

\author{
C. M.Asplin*, P. M. Hollander** and J. P. Palmer \\ Diabetes Research Center and Department of Medicine, University of Washington, Seattle, Washington, USA
}

\begin{abstract}
Summary. To investigate the mechanism whereby changes in plasma glucose level alter human pancreatic A-cell activity in vivo, A-cell activity was determined during manipulation of plasma glucose and pancreatic B-cell activity by insulin and glucose infusions. A-cell activity (the acute immunoreactive glucagon response to intravenous arginine, $0-10 \mathrm{~min}$ ) rose from $482 \pm 125$ to $968 \pm 191 \mathrm{pg} \cdot \mathrm{ml}^{-1} \cdot 10 \mathrm{~min}^{-1}$ (mean \pm SEM) when the plasma C-peptide level (a measure of B-cell activity) was suppressed from $2164 \pm 365$ to $872 \pm 162 \mathrm{pg} / \mathrm{ml}$ by an insulin infusion at euglycaemia (employing the glucose clamp technique) in six normal subjects. Raising plasma glucose to $6.7 \mathrm{mmol} / 1$ during the same insulin infusion returned mean Cpeptide $(2688 \pm 581 \mathrm{pg} / \mathrm{ml})$ and the acute glucagon response to arginine $\left(447 \pm 146 \mathrm{pg} \cdot \mathrm{ml}^{-1} \cdot 10 \mathrm{~min}^{-1}\right)$ close to basal levels.
\end{abstract}

Individual changes in the acute glucagon response to arginine followed the C-peptide changes. The mean change in the acute glucagon response to arginine per unit change in plasma glucose $(-191 \pm 36)$ was similar to that seen when plasma glucose was raised to twice basal levels in six different subjects without an insulin infusion ( $-159 \pm 45)$. This suggests that, when plasma glucose is raised to about twice basal level in vivo, the major factor in suppressing A-cell activity is the concurrent change in B-cell activity rather than direct effects of glucose or circulating insulin on the A cell.

Key words: Pancreatic A cell, paracrine, glucose clamp, C-peptide.
The control of glucagon secretion from the pancreatic A cell is probably mediated via complex interactions between multiple factors including neural influences, circulating intermediary metabolites and gastro-intestinal hormones. The close anatomical relationship between the hormonally active cells of the endocrine pancreatic islet [1] also raises the possibility of control of the A cell by other islet cells; such local control has been termed paracrine.

We have shown recently that, when the plasma glucose concentration is raised in normal subjects [2], the acute plasma immunoreactive glucagon (IRG) response to intravenous arginine, which is used as a measure of pancreatic A-cell activity, is suppressed. This suppression of A-cell activity could be mediated by a variety of factors. Changes in plasma glucose could directly affect the A cell, or changes in plasma glucose could alter pancreatic B-cell activity and such changes in the B cell

\footnotetext{
* Present address: Diabetes Research Center, Blue Ridge Hospital, Charlottesville, Virginia, USA

** Present address: St. Louis Park Medical Center, Minneapolis, Minnesota, USA
}

have a paracrine action on the A cell. Alternatively the secretory product of the B cell (insulin, IRI) could influence the A cell directly or by altering the circulating levels of intermediary metabolites, the changes in these fuels then affecting the A cell.

We have also demonstrated [3] that, in man, paracrine B-cell activity inhibits A-cell activity in vivo, and that, in the absence of functioning $B$ cells, increments in both glucose and insulin plasma levels inhibit A-cell activity $[3,4]$. Thus, to determine which of these mechanisms is important in the suppression of A-cell activity when plasma glucose is raised in normal subjects, we have studied the relationship between A-cell activity and B-cell activity (assessed by plasma C-peptide measurements), plasma glucose and plasma IRI levels, following manipulations of plasma glucose, IRI and Cpeptide levels by various insulin and/or glucose infusions.

\section{Subjects and methods}

Six normal healthy male volunteers (age 18-30 years) were studied in hospital after informed consent had been obtained and Ethical Com- 
Table 1. The pre-arginine injection plasma levels of glucose, insulin and C-peptide and the acute glucagon responses to arginine

\begin{tabular}{|c|c|c|c|c|c|c|}
\hline \multirow{2}{*}{$\begin{array}{l}\text { Pre-arginine injection } \\
\text { plasma levels of }\end{array}$} & \multicolumn{3}{|l|}{ First study } & \multicolumn{3}{|l|}{ Second study } \\
\hline & Basal & Euglycaemia & Hyperglycaemia & Basal & 1 & 2 \\
\hline Glucose $(\mathrm{mmol} / \mathrm{l})$ & $3.9 \pm \quad 0.2$ & $3.9 \pm \quad 0.2$ & $6.7 \pm \quad 0.1$ & $4.8 \pm 0.2$ & $9.0 \pm \quad 0.1$ & $18.7 \pm \quad 0.7$ \\
\hline Insulin (mU/l) & $7 \pm 2$ & $156 \pm 11$ & $164 \pm 11$ & $19 \pm 2$ & $90 \pm 17$ & $184 \pm 56$ \\
\hline C-peptide (pg/ml) & $2164 \pm 365$ & $872 \pm 162$ & $2688 \pm 581$ & $2207 \pm 399$ & $6122 \pm 813$ & $11481 \pm 922$ \\
\hline
\end{tabular}

Results expressed as mean $\pm \mathrm{SEM}$

mittee approval acquired. They were all within $5 \%$ of their ideal body weight using the Metropolitan Life Insurance Company tables (1959).

\section{Study protocol}

Following an overnight fast, IV cannulae were inserted into both antecubital fossae and into a vein on the back of the hand. The hand was placed in a thermostatically controlled hot hand box for the collection of arterialized venous blood [5]. After a 45-min basal period, during which blood was drawn at 15 min intervals, a 5 -g IV bolus of arginine was administered over $30 \mathrm{~s}$. Blood samples were withdrawn at 2,3,4, $5,6,8,10,20$ and $30 \mathrm{~min}$ after this arginine injection. An infusion of high purity porcine insulin (Eli Lilly, Indianopolis, Indiana, USA) in $0.9 \%$ saline, mixed with $10 \mathrm{ml}$ of the subjects own blood (to minimize the surface absorption of insulin) [6] was then started using a 50-ml syringe and pump. Insulin was infused at $1 \mathrm{mU} \cdot \mathrm{kg}^{-1} \cdot \mathrm{min}^{-1}$ for $90 \mathrm{~min}$. Blood was drawn at 5 -min intervals for $60 \mathrm{~min}$, then another arginine bolus injection was given with blood sampling as above for $30 \mathrm{~min}$.

\section{Glucose clamp technique}

Plasma glucose was maintained at basal levels by a $10 \%$ dextrose infusion using the glucose clamp technique [7], with arterialized plasma glucose concentrations being determined every $5 \mathrm{~min}$. Then with the insulin infusion unchanged, the glucose pump was turned to maximum delivery rate (approximately $55 \mathrm{mmol} / \mathrm{min}$ ) and the plasma glucose level determined every minute until the plasma glucose level was $6.7 \mathrm{mmol} / 1$ (from 5 to $8 \mathrm{~min}$ ). The plasma glucose level was then clamped for $90 \mathrm{~min}$ with blood samples as before. After $60 \mathrm{~min}$, a third arginine injection was given with blood sampling over the next $30 \mathrm{~min}$. The coefficient of variation of the plasma glucose level was $<3 \%$.

\section{Other studies}

We have also compared the C-peptide, IRI and acute glucagon responses to arginine in the above study with those obtained in six normal subjects who received glucose infusions alone [2]. These infusions were designed to clamp the plasma glucose level at approximately $9 \mathrm{mmol} / \mathrm{l}$ and then at approximately $20 \mathrm{mmol} / \mathrm{l}$.

\section{Sampling and assays}

Blood samples were collected into chilled tubes $\left(4^{\circ} \mathrm{C}\right)$, with IRG samples collected into benzamidine, those for C-peptide into aprotinon, centrifuged immediately, and frozen at $-20^{\circ} \mathrm{C}$ until analysis. Plasma IRG was measured by radioimmunoassay using a polyethylene glycol separation [8] and plasma IRI by a double-antibody radioimmunoassay [9]. The plasma C-peptide radioimmunoassay [10] used antibody M1230 (Novo). Plasma glucose was measured using a Yellow Springs analyzer (Yellow Springs, Ohio, USA), results being available $40 \mathrm{~s}$ after sample collection. The haematocrit was used to correct whole blood to plasma glucose values. The acute IRG response to arginine was calculated as the incremental area under the IRG response curve from $0-10$ min following each arginine injection. The ability of the change in plasma glucose level to influence (or modulate) the acute glucagon response is expressed as the modulating effect of unit change in plasma glucose on the A-cell response to arginine [2]. Thus the modulating effect of glucose on the pancreatic A cell was calculated for each individual and is a numerical representation of the slope of the graph which plots acute glucagon response as a function of the plasma glucose level.

\section{Statistical analysis}

Results are shown as mean \pm SEM and statistically significant differences between acute glucagon response to arginine, IRI and C-peptide values were tested by the Wilcoxon rank sum test.

\section{Results}

\section{First study: Basal state and insulin infusion at euglycaemia}

The mean $30 \mathrm{~min}$ pre-arginine levels of plasma C-peptide, IRI and glucose and the acute glucagon response to arginine in the basa state and during the insulin infusion at euglycaemia are shown in Table 1 . The mean pre-arginine C-peptide levels fell from $2164 \pm 365$ to $872 \pm 162 \mathrm{pg} / \mathrm{ml}$ when the insulin infusion (with euglycaemia) was employed ( $p<0.01$ ), and this was associated with a rise in the acute glucagon response to arginine $\left(482 \pm 125\right.$ to $\left.968 \pm 191 \mathrm{pg} \cdot \mathrm{ml}^{-1} \cdot 10 \mathrm{~min}^{-1}\right)$.

\section{Insulin infusion at hyperglycaemia}

With the same insulin infusion but now the plasma glucose level raised to $6.7 \pm 0.1 \mathrm{mmol} / \mathrm{l}$, the C-peptide rose to $2688 \pm 581 \mathrm{pg} / \mathrm{ml}(p<0.01$ a value similar to that seen in the basal state). The change in IRI levels with the glucose infusion $(156 \pm 11$ to $164 \pm 11 \mathrm{mU} / \mathrm{l})$ was not statistically significant but the acute glucagon response to arginine fell to $447 \pm 146 \mathrm{pg} \cdot \mathrm{ml}^{-1} \cdot 10 \mathrm{~min}^{-1}$ $(p<0.01)$, similar to that obtained in the basal state (Table 1). The changes in individual acute glucagon responses to arginine and plasma glucose levels are shown in Figure 1. The mean \pm SEM slope of this line is $-191 \pm 36$ (i. e. the modulating effect of plasma glucose 


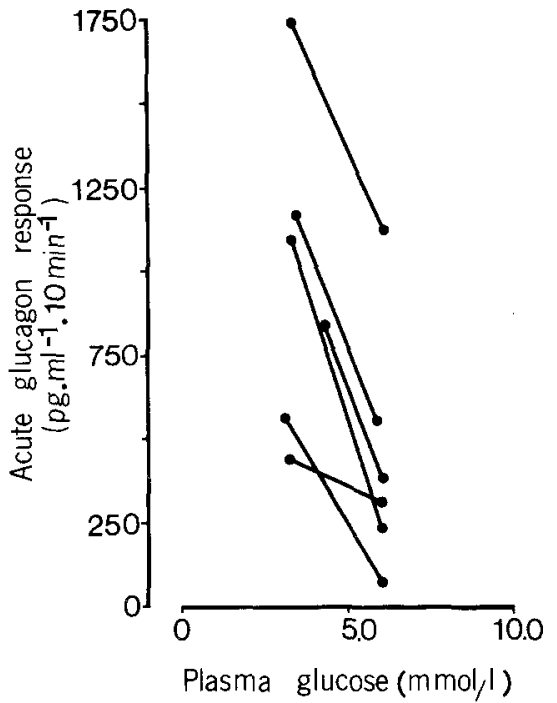

Fig. 1. The acute immunoreactive glucagon response to arginine at basal plasma glucose and $6.7 \mathrm{mmol} / 1$ in six normal subjects. The slope of each line is the change in acute glucagon response per unit change in plasma glucose: the mean \pm SEM slope is $-191 \pm 36$

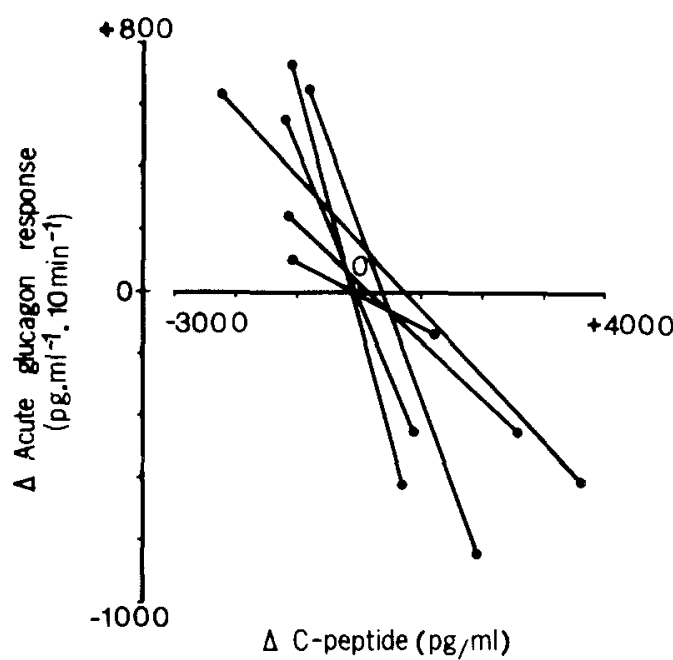

Fig. 2. The individual changes in acute glucagon response to arginine and C-peptide as the C-peptide level is lowered (by insulin infusion at euglycaemia), then raised (during the same insulin infusion with the plasma glucose clamped at $6.7 \mathrm{mmol} / \mathrm{l}$ )

on the acute glucagon response to arginine). The acute glucagon response to arginine data are for the second and third arginine injections.

\section{Individual C-peptide and acute glucagon responses to arginine}

The individual changes in C-peptide and acute glucagon responses to arginine are shown in Figure 2. C-peptide falls and the acute glucagon response to arginine rises between the first and second arginine injections, and between the second and third arginine injections $\mathrm{C}$ peptide rises and acute glucagon response to arginine falls.

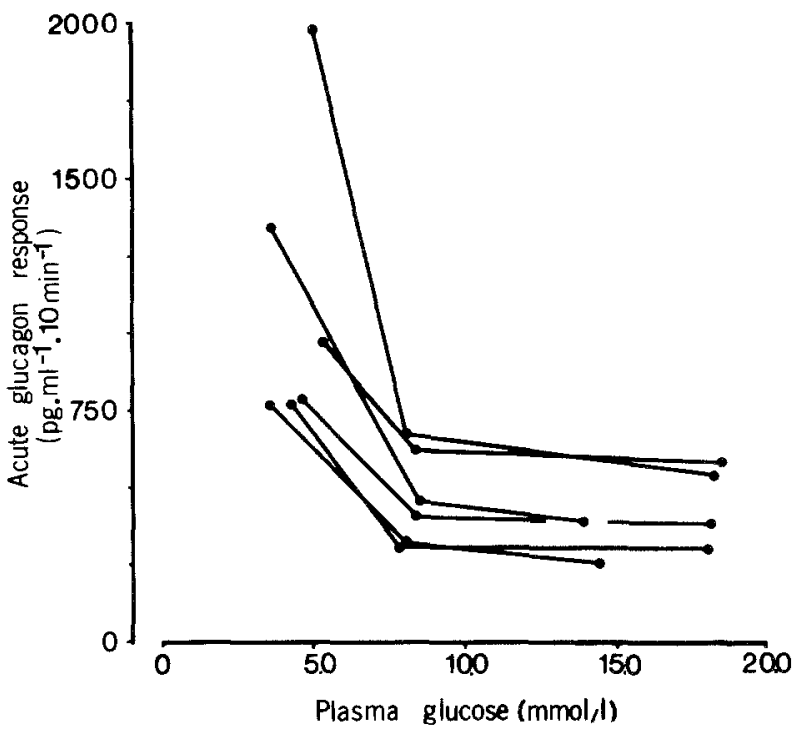

Fig. 3. The individual acute immunoreactive glucagon responses to arginine at basal plasma glucose, when the mean plasma glucose level had been raised to $9.0 \mathrm{mmol} / 1$ and then to $18.7 \mathrm{mmol} / \mathrm{l}$. The slope of each line is the change in the acute glucagon response to arginine per unit change in plasma glucose. The mean $\pm S E M$ slope for the first plasma glucose change is $-159 \pm 45$ and for the second plasma glucose change is $-6.2 \pm 1.9$

\section{Second study}

Table 1 also shows the pre-arginine plasma levels of Cpeptide, IRI and glucose and the acute glucagon responses to arginine. In these six subjects the mean plasma glucose level was manipulated firstly from basal $(4.83 \pm 0.22 \mathrm{mmol} / \mathrm{l})$ to $9.0 \pm 0.1 \mathrm{mmol} / \mathrm{l}$ with a rise in C-peptide from $2207 \pm 399$ to $6122 \pm 813 \mathrm{pg} / \mathrm{ml}(p<$ 0.01 ). There was a fall in the mean acute glucagon response to arginine from $1099 \pm 397$ to $464 \pm 46 \mathrm{pg}$. $\mathrm{ml}^{-1} \cdot 10 \mathrm{~min}^{-1}(p<0.01)$. Then the plasma glucose was raised again to $18.7 \pm 0.7 \mathrm{mmol} / 1$ causing a further rise in C-peptide level to $11481 \pm 922 \mathrm{pg} / \mathrm{ml}(p<0.01)$. A further fall occurred in the acute glucagon response to arginine to $410 \pm 40 \mathrm{pg} \cdot \mathrm{ml}^{-1} \cdot 10 \mathrm{~min}^{-1}(p<0.01)$. Figure 3 shows, for these six subjects, the individual plasma glucose and the acute glucagon responses to arginine for each of the three plasma glucose levels. The mean slope was $-159 \pm 45$ for the first plasma glucose change and $-6.2 \pm 1.9$ for the second plasma glucose change.

\section{Discussion}

These two studies have shown that the suppression of pancreatic A-cell activity by small rises in plasma glucose level is related to concurrent changes in B-cell activity. The suppression of A-cell activity when the plasma glucose is raised could be due to many causes [2], including a direct suppressive effect of rising plasma glucose levels on the A cell [4] or a suppressive effect of the insulin infusion on A-cell activity [3]. These later 
two observations can only be made in vivo in C-peptide-negative insulin-dependent diabetic patients, otherwise changes in B-cell activity, brought about by the glucose or insulin infusions, could influence the A-cell $[3,4]$.

In the normal subjects studied here, the changes in A-cell activity follow the changes in B-cell activity (acute glucagon response to arginine and C-peptide levels respectively), brought about by the insulin/glucose infusions. Thus in the first study, the acute glucagon response to arginine is raised when insulin is infused, with the maintenance of the euglycaemia (first and second arginine injections), as the C-peptide level falls. Then, with the same insulin infusion and plasma glucose raised to $6.7 \mathrm{mmol} / 1$, the acute glucagon response to arginine falls back close to basal levels. The value for the plasma glucose level was chosen so as to return the Cpeptide levels close to basal.

The acute glucagon responses to arginine challenge were compared, between the second and third arginine injections, by multiple regression analysis. It appeared that all changes in the acute glucagon response to arginine could be accounted for by the C-peptide changes. There appeared to be no independent effect of glucose. Furthermore, as shown in Figure 2, there was a close linear relationship between individual changes in Cpeptide and changes in the acute glucagon response to arginine. In Figure 2, a perfect linear relationship between the C-peptide levels and the acute glucagon response to arginine would result in all the lines passing through zero.

We next considered the change in acute glucagon response to arginine per unit change in plasma glucose, i.e. the slope of the lines in Figures 1 and 3. These slopes are similar in the first study and the first part of the second study. In the first study, plasma glucose was raised from basal to $6.7 \mathrm{mmol} / 1$ during an insulin infusion, and in the first part of the second study, plasma glucose was raised from basal to $9.0 \mathrm{mmol} / 1$ (no insulin infusion). Thus it seems that, when the plasma glucose level is raised to about twice basal, the fall in A-cell activity is virtually all mediated by the change in B-cell activity induced by the glucose rise. Also the B-cell influences on the A cell are produced mainly by a paracrine mechanism rather than by the general metabolic effects of insulin action.

In the second part of the second study when the plasma glucose was raised to about four times basal, the acute glucagon response to arginine fell further. However, there was a much smaller fall in the acute glucagon response to arginine per unit change in plasma glucose than when the plasma glucose level was raised to only twice basal. This was not because of a diminished B-cell response to the plasma glucose rise because the C-peptide and IRI levels continue to rise. Thus, when the plasma glucose level rises from twice to four times basal (the second part of the second study), the modulating effect of plasma glucose on the acute glucagon response to arginine is close to that seen in C-peptide negative insulin-dependent diabetic patients. In such diabetics a direct effect of glucose on the A cell is postulated [4], there being no possibility of B-cell/A-cell interaction.

The pre-arginine IRG levels fell in both studies. This is not the explanation for the changes in the acute glucagon response to arginine that were seen. This is because the acute glucagon response to arginine is a response above pre-stimulus IRG levels. Also, the absolute peak IRG levels obtained mimicked very closely the acute glucagon response to arginine changes. However it does suggest that basal IRG may be under a different control mechanism than stimulated IRG [3]. The sites of origin of the IRG are also probably different, the acute glucagon response to arginine is 3500 dalton glucagon of pancreatic origin [11], whereas IRG from extra-pancreatic sources contributes to basal IRG [12].

There is controversy as to the effect of glucose on the A cell in diabetic patients and the degree of abnormality of A-cell activity in diabetes [13]. Our studies would suggest that data showing an effect of glucose on the A cell in diabetic patients would need to take account of the plasma glucose range studied, the presence of residual B-cell function, whether stimulated or basal IRG was measured and the effect of any administered insulin. There is great individual variation in the acute glucagon response to arginine in normal subjects (for example, the mean acute glucagon response is much larger in the second group of normal subjects studied than in the first; Table 1). Thus it is important, when assessing change in A-cell activity brought about by changes in the plasma glucose level, to use each individual as his own control rather than just comparing different groups of subjects at various plasma glucose levels.

When the plasma glucose level is raised to about twice basal by a glucose infusion, the suppression of pancreatic A-cell activity observed is mainly mediated via paracrine B-cell activity. A direct effect of glucose on the A cell or an effect of insulin in the general circulation, altering metabolite levels and so affecting the A cell, appears to be of little importance. However, this paracrine control appears much less relevant when the plasma glucose is further raised to about four times basal levels.

\footnotetext{
Acknowledgements. The authors are grateful to R.Potts and J.Holly for their excellent technical assistance, and to G.Smith and M.Pedersen for typing the manuscript. This work was supported, in part, by NIH grant AM 17047, USPHS grant SEA 790878, and a grant from the Juvenile Diabetes Foundation. Dr. Asplin was the recipient of a Fellowship Award from the American Diabetes Association, Washington Affiliate, and an award from the Oxford Regional Health Authority. Dr. Hollander was the recipient of a National Institutes of Health Research Fellowship (AM 06118). Dr. Palmer is the recipient of a Clinical Investigator Award (1K08 AM 00535). Presented, in part, at the American Diabetes Association meeting, June 1982, the European Association for the Study of Diabetes, September 1982, and the International Diabetes Federation meeting, November 1982.
} 


\section{References}

1. Orci L, Unger RH (1975) Functional subdivision of islets of Langerhans and possible role of D cells. Lancet 2: 1243-1244

2. Hollander PM, Asplin CM, Palmer JP (1982) Glucose modulation of insulin and glucagon in non-diabetic and diabetic man. Diabetes 31: 489-495

3. Asplin CM, Paquette TL, Palmer JP (1981) In vivo inhibition of glucagon secretion by paracrine beta cell activity in man. J Clin Invest 68: 314-318

4. Asplin CM, Raghu P, Dornan T, Palmer JP (1983) Independent action of glucose on the pancreatic A cell in vivo. Metabolism 32: 292-295

5. McGuire EAH, Helderman JH, Tobin JD, Andres R, Berman M (1976) Effects of arterial versus venous sampling on analysis of glucose kinetics in man. J Appl Physiol 41: 565-573

6. Sonksen PH (1976) Carrier solutions for low-level intravenous insulin infusion. Br Med J 1: 151-152

7. DeFronzo RA, Robin JD, Andres R (1979) Glucose clamp technique: a method for quantifying insulin secretion and resistance. Am J Physiol 6: E214-223

8. Henquin JC, Malvaux P, Lambert AE (1974) Glucagon immunoassay using polyethylene glycol to precipitate antibody-bound hormone. Diabetologia 10: 61-68
9. Morgan CR, Lazrow A (1963) Immunoassay of insulin: two antibody systems. Diabetes 21: 115-126

10. Faber OK, Markussen J, Naithani VK, Binder C (1976) Production of antiserum to synthetic benzyloxycarbonyl-C-peptide of human proinsulin. Hoppe Seyler's Z. Physiol Chem 357: 751-757

11. Werner PL, Palmer JP (1978) Immunoreactive glucagon responses to oral glucose, insulin infusion and deprivation and somatostatin in pancreatectomized man. Diabetes 27: 1005-1012

12. Tiengo A, Bessioud M, Valverde I, Tabbi-Anneni A, Delprato S, Alexandre J, Assan R (1982) Absence of islet alpha cell function in pancreatectomized patients, Diabetologia $22: 25-32$

13. Unger RH (1978) Role of glucagon in the pathogenesis of diabetes: the status of the controversy. Metab Clin Exp 27: 1691-1709

Received: 7 February 1983

and in revised form: 24 November 1983

Dr. C. M. Asplin

Diabetes Research Center

Blue Ridge Hospital

University of Virginia

Monticello Road

Charlottesville, VA 22901

USA 